\title{
CELLULASE PRODUCTION AND CONVERSION OF RICE STRAW TO LACTIC ACID BY SIMULTANEOUS SACCHARIFICATION AND FERMENTATION
}

\author{
F. I. EL-HAWARYa ${ }^{a}$, Y. S. MOSTAFA ${ }^{a}$ and E. LÁSZLób* \\ ${ }^{a}$ Microbiology Department, Faculty of Agriculture, Mansoura University, Mansoura. Egypt \\ ${ }^{\mathrm{b}}$ Department of Agricultural Chemical Technology, Budapest University of Technology and Economics, \\ H-1521 Budapest, Szt. Gellért tér 4. Hungary
}

(Received: 22 November 1999; revision received: 18 January 2001; accepted: 27 March 2001)

Factors affecting the cellulase production of Aspergillus niger using sugar cane bagasse as carbon source were investigated. The highest enzyme activities were obtained, when the culture medium was supplemented with $0.133 \%$ tryptone as nitrogen source. The rate of cellulase production was considerably increased when $0.5 \%$ Tween 60 was added to the production medium. For FPA and $\beta$-glucosidase production $\mathrm{pH}$ 5.0, while for CMC-ase $\mathrm{pH} 5.5$ was found to be optimal. The highest cellulase activities were obtained at $30{ }^{\circ} \mathrm{C}$ and 300 r.p.m. The highest saccharification degree was achieved, when alkali treated rice straw was used as substrate. The main objective of the present study was to examine the possibilities of lactic acid production from alkali treated rice straw using simultaneous saccharification and fermentation technique with $T$. koningii cellulases and L. delbrueckii. The highest conversion of cellulose was obtained using $6 \%$ alkaline treated rice straw supplemented with $1.2 \mathrm{mg}$ enzyme/g substrate at $\mathrm{pH} 4.8$ and $45^{\circ} \mathrm{C}$.

Keywords: rice straw, saccharification, SSF, lactic acid, cellulase production, Aspergillus niger, Trichoderma koningii, Lactobacillus delbrueckii

Lignocellulosic biomass is considered to be one of the most important resources for the production of glucose, alternative fuels and chemicals. For instance, the annual production of sugar cane bagasse is about 3.40 million tons in Egypt. Lactic acid has been produced commercially by fermentation since 1881 . Today, the amount of lactic acid produced via biological process makes up to $50 \%$ of the total lactic acid production (HOFVENDAHL \& HAHN-HAGERDAL, 1997). Lactic acid is mainly used in the various fields of food industry as preservative agent. It can also be used as a precursor in the

* To whom correspondence should be addressed. Fax: +3614632598,

E-mail: laszlo@chem.bme.hu 
production of other organic compounds such as acrylic acid, acetaldehyde, and ethanol. Recently, lactic acid has drawn a lot of attention because of the achievement in the development of biodegradable poly-lactic plastics. Furthermore, lactic acid has stimulating effects on plant (KINNERSLEY et al., 1990; MulLIGAN et al., 1991; MERCIER et al., 1992; NORTON et al., 1994). A typical process configuration for bioconversion of lignocellulosic biomass to lactic acid consists of two steps i.e. enzymatic hydrolysis of the cellulose content of the raw material and the fermentation of the sugars formed in the hydrolysis to lactic acid using a suitable chosen bacterium (LADISH \& SVARCZKOPF, 1991; Demiric et al., 1993; KATZen \& MonceauX, 1995; Hahn-Hagerdal, 1996; KADEMIC \& BARATTI, 1996; OLSSON \& HAHN-HAGERDAL, 1996). A novel approach, which has been successfully applied in the bioconversion of lignocellulosic substrates to fuel ethanol (LEZINOU et al., 1994; PHILIPPIDIS \& SMITH, 1995), is the so-called simultaneous saccharification and fermentation (SSF) technique. During SSF the enzymatic hydrolysis of the raw material is performed together with the fermentative conversion of the produced sugars to lactic acid in one reaction vessel. In general, the SSF has three important advantages compared to the two step separate hydrolysis and fermentation technique. Namely, the capital cost of the process can considerably be decreased, since only one reactor is needed; material losses due to handling can be minimized; and inhibition of the enzymes caused by the liberated sugars can be avoided, since they are converted to the end product in the same instance as they are formed (PARAJO et al., 1997).

In the present work, the cellulase production of Aspergillus niger was studied using sugar cane bagasse as carbon source. The effect of quality and quantity of nitrogen source, $\mathrm{pH}$, addition of surfactants, incubation temperature, and agitation speed was investigated. The other main objective of this present study was the examination of lactic acid production applying the SSF process using alkali treated rice straw using Trichoderma koningii cellulases together with Lactobacillus delbrueckii.

\section{Materials and methods}

\subsection{Microorganism}

Freeze-dried cultures of Aspergillus niger 00632, Trichoderma koningii 2691, and Lactobacillus delbrueckii 01357 were obtained from the National Collection of Agricultural and Industrial Microorganisms (NCAIM) Budapest, Hungary.

\subsection{Substrates}

In the present study rice straw, cotton stalks and sugar cane bagasse were used as substrates. All raw materials were sun dried for 5 days and their particle size was 
reduced to $1-2 \mathrm{~cm}$ by manual method. A portion of the dried and ground materials was treated with $2 \mathrm{M} \mathrm{NaOH}$ at $30{ }^{\circ} \mathrm{C}$ for $48 \mathrm{~h}$, while the other portion with $1 \mathrm{wt} \% \mathrm{H}_{2} \mathrm{SO}_{4}$ at $120^{\circ} \mathrm{C}$ for $100 \mathrm{~min}$ (CARRASCO et al., 1994). The pretreated materials were thoroughly washed with tap water, oven dried at $70-80{ }^{\circ} \mathrm{C}$ and milled before used.

\subsection{Media and culture conditions}

Fungal stock cultures were maintained on standard PDA slants at $4{ }^{\circ} \mathrm{C}$. Three ml of spore suspension obtained from a 7-day old PDA slant of A. niger was used to initiate growth in an E-flask containing $50 \mathrm{ml}$ of sterile production medium (pH 5.0) in which the concentration of nutrients were: $7 \mathrm{~g} \mathrm{l}^{-1}\left(\mathrm{NH}_{4}\right)_{2} \mathrm{SO}_{4}, 10 \mathrm{~g} \mathrm{l}^{-1} \mathrm{KH}_{2} \mathrm{PO}_{4}, 1.5 \mathrm{~g} \mathrm{l}^{-1}$ $\mathrm{MgSO}_{4} \cdot 7 \mathrm{H}_{2} \mathrm{O}, 1.5 \mathrm{~g} \mathrm{l}^{-1} \mathrm{CaCl}_{2} \cdot 2 \mathrm{H}_{2} \mathrm{O}, 1.5 \mathrm{~g} \mathrm{l}^{-1}$ urea and $1 \mathrm{~g} \mathrm{l}^{-1}$ glucose together with $3 \mathrm{wt} \%$ sugar cane bagasse as carbon source. Trace elements were also added: $25 \mathrm{mg} \mathrm{l}^{-1}$ $\mathrm{FeSO}_{4} \cdot 7 \mathrm{H}_{2} \mathrm{O}, 10.3 \mathrm{mg} \mathrm{l}^{-1} \mathrm{MnSO}_{4} \cdot 4 \mathrm{H}_{2} \mathrm{O}, 7 \mathrm{mg} \mathrm{l}^{-1} \mathrm{ZnSO}_{4} \cdot 7 \mathrm{H}_{2} \mathrm{O}$, and $18.3 \mathrm{mg} \mathrm{l}^{-1}$ $\mathrm{CoCl}_{2} \cdot 6 \mathrm{H}_{2} \mathrm{O}$ (TÜRKER \& MAVITUNA, 1987). Cultures were incubated on a rotary shaker at $30^{\circ} \mathrm{C}$ and 100 r.p.m. The fermentation broth was filtered and the enzyme activities were determined. From a 7-day old PDA slant of $T$. koningii the conidia was suspended in $3 \mathrm{ml}$ of sterile water and was used to inoculate an E-flask containing $50 \mathrm{ml}$ of TÜRKER (1987) medium supplemented with acid treated sugar cane bagasse (ELHAWARY \& MOSTAFA, 2001). The culture was incubated at $30{ }^{\circ} \mathrm{C}$ and 100 r.p.m. The fermentation broth was filtered, precipitated using cold ethanol, dialyzed, lyophilized and used in the SSF experiments.

Lactobacillus delbrueckii 01357 was maintained on agar slants containing $20 \mathrm{~g} \mathrm{l}^{-1}$ glucose, $10 \mathrm{~g} \mathrm{l}^{-1}$ peptone, $10 \mathrm{~g} \mathrm{l}^{-1}$ beef extract, $5 \mathrm{~g} \mathrm{l}^{-1}$ yeast extract, $5 \mathrm{~g} \mathrm{l}^{-1}$ sodium acetate, $2 \mathrm{~g} \mathrm{l}^{-1}$ sodium citrate, $2 \mathrm{~g} \mathrm{l}^{-1} \mathrm{~K}_{2} \mathrm{HPO}_{4}, 0.58 \mathrm{~g} \mathrm{l}^{-1} \mathrm{MgSO}_{4} 7 \mathrm{H}_{2} \mathrm{O}$, $0.21 \mathrm{~g} \mathrm{l}^{-1} \mathrm{MnSO}_{4} \mathrm{H}_{2} \mathrm{O}, 1 \mathrm{ml}$ Tween 80 and $20 \mathrm{~g} \mathrm{l}^{-1}$ agar. The $\mathrm{pH}$ was adjusted to 6.4 . The seed culture was incubated at $45^{\circ} \mathrm{C}$ for $24 \mathrm{~h}$. (ABE \& TAKAGI, 1991). Inoculum for lactic acid production was prepared by transferring 24-h old culture of $L$. delbrueckii to $250 \mathrm{ml}$ E-flasks containing $100 \mathrm{ml}$ of culture medium which had the same composition as described before without any agar added.

\subsection{Enzymatic hydrolysis of pretreated materials}

The enzymatic hydrolysis of the various pretreated substrates was performed at 2 wt\% dry weight content in $0.05 \mathrm{M}(\mathrm{pH} 4.8)$ sodium acetate buffer solution supplemented with $0.2 \mathrm{mg}$ of protein/g of substrate. The hydrolysis mixture was also supplemented with $0.3 \mathrm{~g} \mathrm{l}^{-1}$ sodium azide in order to prevent microbial growth. The $25 \mathrm{ml}$ E-flasks containing a total volume of $10 \mathrm{ml}$ reaction mixture were incubated in a rotary shaker at $50{ }^{\circ} \mathrm{C}$ and 100 r.p.m. After $48 \mathrm{~h}$ of hydrolysis, hydrolysates were centrifuged at 4000 r.p.m. for $30 \mathrm{~min}$ and the supernatants were collected. The total 
reducing sugar content of the various supernatants were analyzed by using the so-called DNS procedure (MILLER, 1959). Saccharification percentage was calculated using the following equation (MANDELS et al., 1976):

$$
\text { Saccharification }(\%)=\frac{\text { Total reducing sugar }\left(\mathrm{mg} \mathrm{ml}^{-1}\right) \times 0.9 \times 100}{\text { Initial substrate concentration }\left(\mathrm{mg} \mathrm{ml}^{-1}\right)}
$$

\subsection{Fermentation of hydrolysates}

The hydrolysates obtained were supplemented with $6 \mathrm{wt} \%$ yeast extract, $0.167 \mathrm{wt} \%$ sodium acetate, $0.167 \mathrm{wt} \%\left(\mathrm{NaPO}_{3}\right)_{\mathrm{n}}, 0.1 \mathrm{wt} \% \mathrm{MgSO}_{4} \cdot 7 \mathrm{H}_{2} \mathrm{O}, 0.005 \mathrm{wt} \%$ $\mathrm{FeSO}_{4} 7 \mathrm{H}_{2} \mathrm{O}$ and $0.005 \mathrm{wt} \% \mathrm{MnSO}_{4} \mathrm{H}_{2} \mathrm{O}$. Before inoculation the $\mathrm{pH}$ was adjusted to 4.8. In order to prevent acidification during the lactic acid fermentation $5 \mathrm{wt} \% \mathrm{CaCO}_{3}$ was added to the medium. Growth was initiated using vegetative cells of $L$. delbrueckii in a $100 \mathrm{ml}$ E-flask containing $50 \mathrm{ml}$ of nutrient supplemented and sterilized hydrolysate. The inoculum contained $10(\mathrm{v} / \mathrm{v}) \%$ of the medium. The fermentation experiments were carried out at $45^{\circ} \mathrm{C}$ for 6 days.

\subsection{Simultaneous saccharification and fermentation}

SSF experiments were carried out in $100 \mathrm{ml}$ static E-flasks containing $50 \mathrm{ml}$ of sterilized medium incubated at $45^{\circ} \mathrm{C}$. The composition of the SSF medium was $60 \mathrm{~g} \mathrm{l}^{-1}$ pretreated material, $60 \mathrm{~g} \mathrm{l}^{-1}$ yeast extract, $1.67 \mathrm{~g} \mathrm{l}^{-1}$ sodium acetate, $1.67 \mathrm{~g} \mathrm{l}^{-1}$ $\left(\mathrm{NaPO}_{3}\right)_{\mathrm{n}}, 1.0 \mathrm{~g} \mathrm{l}^{-1} \mathrm{MgSO}_{4} 7 \mathrm{H}_{2} \mathrm{O}, 0.05 \mathrm{~g} \mathrm{l}^{-1} \mathrm{FeSO}_{4} 7 \mathrm{H}_{2} \mathrm{O}$ and $0.05 \mathrm{~g} \mathrm{l}^{-1} \mathrm{MnSO}_{4} \mathrm{H}_{2} \mathrm{O}$. The $\mathrm{pH}$ was adjusted to 4.8 . To prevent acidification due to lactic acid formation $0.6 \mathrm{~g}$ $\mathrm{CaCO}_{3} / \mathrm{g}$ substrate was added to the medium. The SSF medium was supplemented with $0.2 \mathrm{mg}$ of protein produced by $T$. koningii/g of substrate. The $L$. delbrueckii inoculum contained $10(\mathrm{v} / \mathrm{v}) \%($ ABE \& TAKAGI, 1991).

\subsection{Measurement of enzyme activities}

Filter paper activity (FPA) was measured according to MANDELS and co-workers' (1976) procedure. The reaction mixture containing $0.5 \mathrm{ml}$ of $0.05 \mathrm{M}$ acetate buffer $(\mathrm{pH}$ $4.8)$ and $0.5 \mathrm{ml}$ of culture filtrate, was incubated together with a $1 \times 3 \mathrm{~cm}(25 \mathrm{mg})$ strip of Whatman No. 1 filter paper at $50{ }^{\circ} \mathrm{C}$ for $60 \mathrm{~min}$. The enzymatic reaction was terminated by addition of $1 \mathrm{ml}$ DNS reagent (MILLER, 1959). After $5 \mathrm{~min}$ of boiling and addition of $10 \mathrm{ml}$ of distilled water the absorbance was measured at $540 \mathrm{~nm}$.

Carboxyl-methyl-cellulose degrading capacity (CMC-ase) was determined by incubating $0.5 \mathrm{ml}$ of enzyme sample together with $0.5 \mathrm{ml}$ of $1 \mathrm{wt} \%$ carboxy-methylcellulose in $0.05 \mathrm{M}$ acetate buffer $(\mathrm{pH} 4.8)$ at $50{ }^{\circ} \mathrm{C}$ for $30 \mathrm{~min}$. The hydrolysis was 
stopped by addition of $1 \mathrm{ml}$ DNS reagent. After boiling for $5 \mathrm{~min}$ and dilution with $10 \mathrm{ml}$ of distilled water the absorbance was read at $540 \mathrm{~nm}$.

For $\beta$-glucosidase activity determination $10 \mu \mathrm{l}$ of culture filtrate was incubated together with $1 \mathrm{ml}$ of $0.67 \mathrm{mM}(0.02 \mathrm{wt} \%)$ p-nitrophenyl- $\beta$-D-glucopyranoside in $0.05 \mathrm{M}$ acetate buffer $(\mathrm{pH} 4.8)$ at $50{ }^{\circ} \mathrm{C}$ for $10 \mathrm{~min}$. The enzymatic reaction was terminated by addition of $3 \mathrm{ml} 0.1 \mathrm{M} \mathrm{NaOH}$ solution. The absorbance was measured at $400 \mathrm{~nm}$ (RECZEY et al., 1990).

\subsection{Determination of lactic acid}

Lactic acid was determined according to BARKER and SUMMERSON's procedure (1996).

\section{Results and discussion}

\subsection{The cellulase production of Aspergillus niger}

In a set of experiments the effect of quality of the nitrogen source was investigated. Ammonium sulfate and urea of basal media were replaced with urea or ammonium sulfate separately or with other organic and inorganic nitrogen sources in such a way that the amount of final nitrogen concentration in the media remained unchanged. The results are summarized in Fig. 1. It can be seen that the cellulase production of A. niger cultivated on untreated sugar cane bagasse as carbon source was higher using tryptone as nitrogen source. Using tryptone the FPA activity was increased by about $20 \%$ compared to the control medium, while the CMC-ase and B-glucosidase activities were increased by 6 and $12 \%$, respectively. The final $\mathrm{pH}$ of the fermentation broth was found to be around 5.2 when tryptone and peptone (which was found to be the second best nitrogen source) were used. There might be a relationship between the final $\mathrm{pH}$ of the culture medium and the cellulase production. The positive effect of complex, organic nitrogen sources on the cellulase production could be due to the presence of growth promoters, in such amounts, which are optimal for fungal growth and enzyme production. The same observations were reported by DOPPELBAUER and co-workers (1987) and MAGNELLI and co-workers (1996).

Since, tryptone proved to be the best alternative nitrogen source resulting in significantly higher enzyme production compared to the standard medium, the effect of tryptone concentration on the cellulase production of A. niger was also studied using untreated sugar cane bagasse as carbon source. Supplementation of the culture medium with $0.133 \%$ tryptone resulted in the highest CMC-ase and $\beta$-glucosidase activities (Fig. 2), however maximum FPA activity was reached when the tryptone concentration was at $0.176 \%$. 


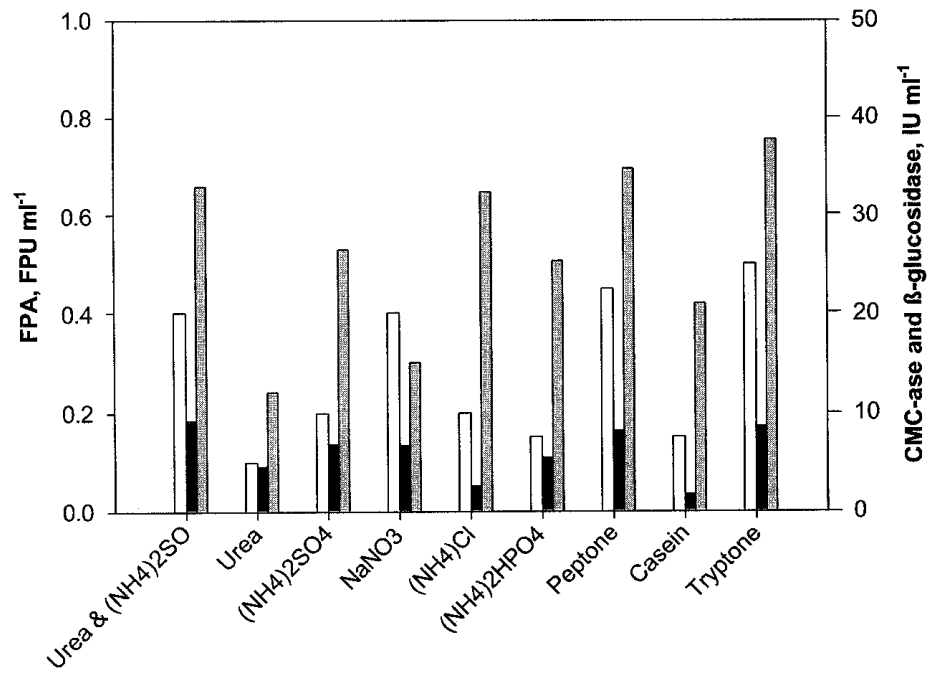

Fig. 1. The effect of nitrogen source on the cellulase production of A. niger using sugar cane bagasse. Filter paper activity (FPA): white bars, $\beta$-glucosidase activity: gray bars; CMC-ase activity: black bars

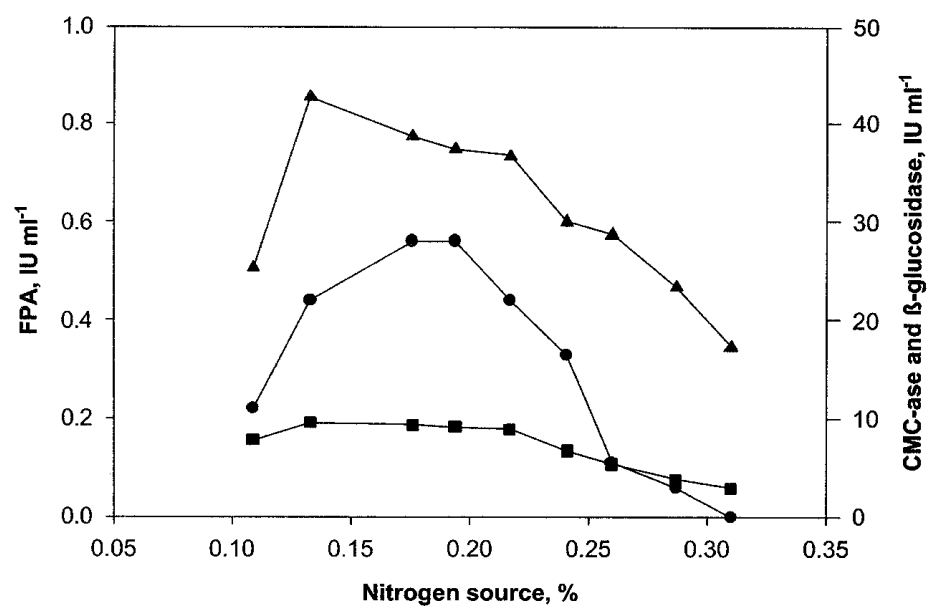

Fig. 2. The effect of nitrogen source concentration on the cellulase production of $A$. niger using sugar cane bagasse. Filter paper activity (FPA): $\bullet$; $\beta$-glucosidase activity: $\boldsymbol{\Lambda}$; CMC-ase activity: 


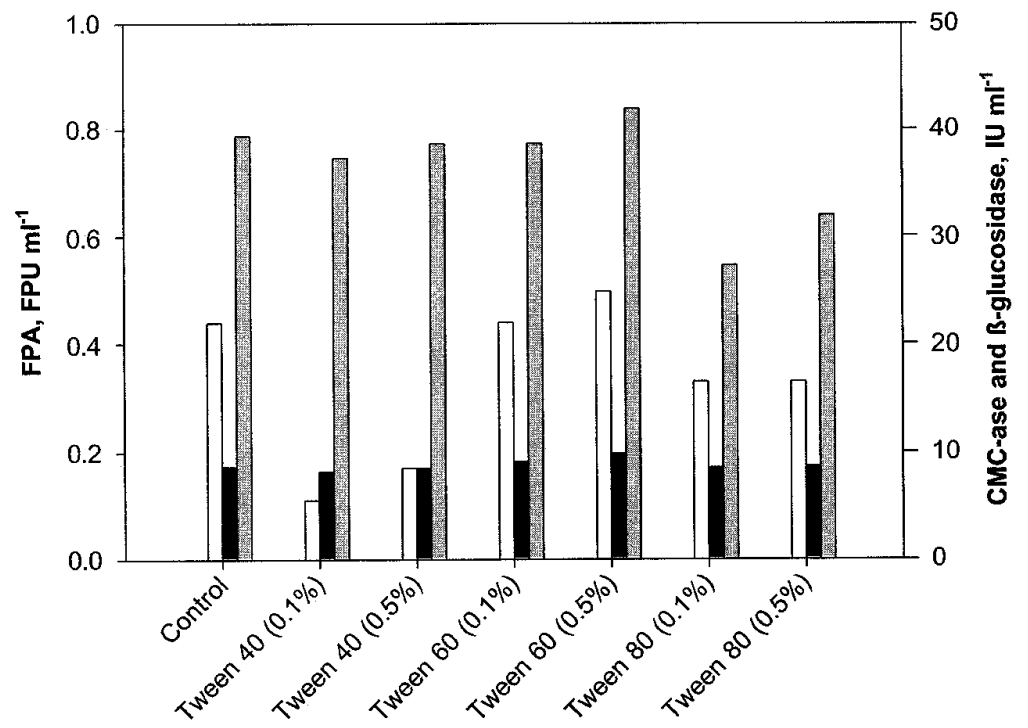

Fig. 3. The effect of surfactants on the cellulase production of A. niger using sugar cane bagasse. Filter paper activity (FPA): white bars; $\beta$-glucosidase activity: gray bars, $\mathrm{CMC}$-ase activity: black bars

The effect of surfactants addition on the enzyme production was studied by supplementing the production medium with Tween 40, 60, 80. Two different concentrations were applied, i.e. $0.1 \%$ and $0.5 \%$, respectively. The addition of Tween 60 at both concentrations stimulated the cellulases production of A. niger (Fig. 3). All enzyme activities were significantly higher compared to the reference fermentation in which no surfactants were added. Similar results were obtained by HUNG and coworkers (1988), LONG and KNAPP (1991) and STUTZENBERGER (1987).

The initial $\mathrm{pH}$ of the cultivation is considered as an important factor effecting the cellulase production. In a set of experiments the initial $\mathrm{pH}$ of the culture medium was varied between 4.0 and 7.0 by addition of either $\mathrm{HCl}$ or $\mathrm{NaOH}$. Figure 4 shows the enzyme activities as the function of the initial $\mathrm{pH}$. The highest FPA and $\beta$-glucosidase activities were obtained at $\mathrm{pH}$ 5.0, however maximal CMC-ase production was observed at $\mathrm{pH}$ 5.5. The results showed good agreement with the data obtained by BASTAWDE (1992).

To evaluate the effect of incubation temperature on the cellulases production of A. niger shake flask experiments were run at various temperatures between 20 and $35{ }^{\circ} \mathrm{C}$. The optimal temperature for enzyme production was found to be $30{ }^{\circ} \mathrm{C}$ (Fig. 5). 


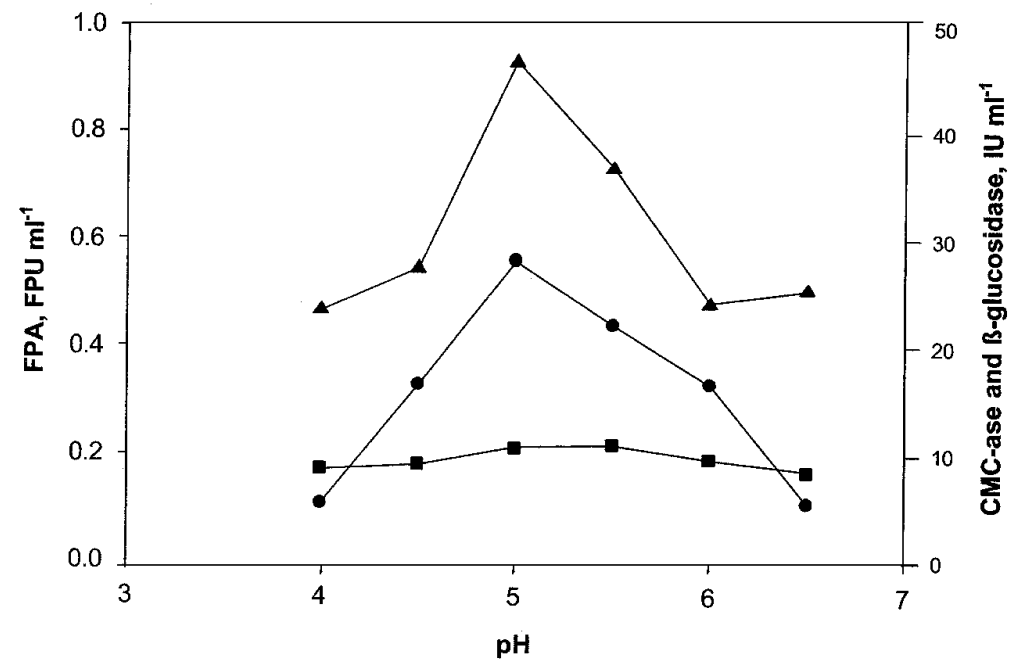

Fig. 4. The effect of initial $\mathrm{pH}$ on the cellulase production of A. niger using sugar cane bagasse. Filter paper activity (FPA): $\bullet ; \beta$-glucosidase activity: $\mathbf{\Delta}$; CMC-ase activity:

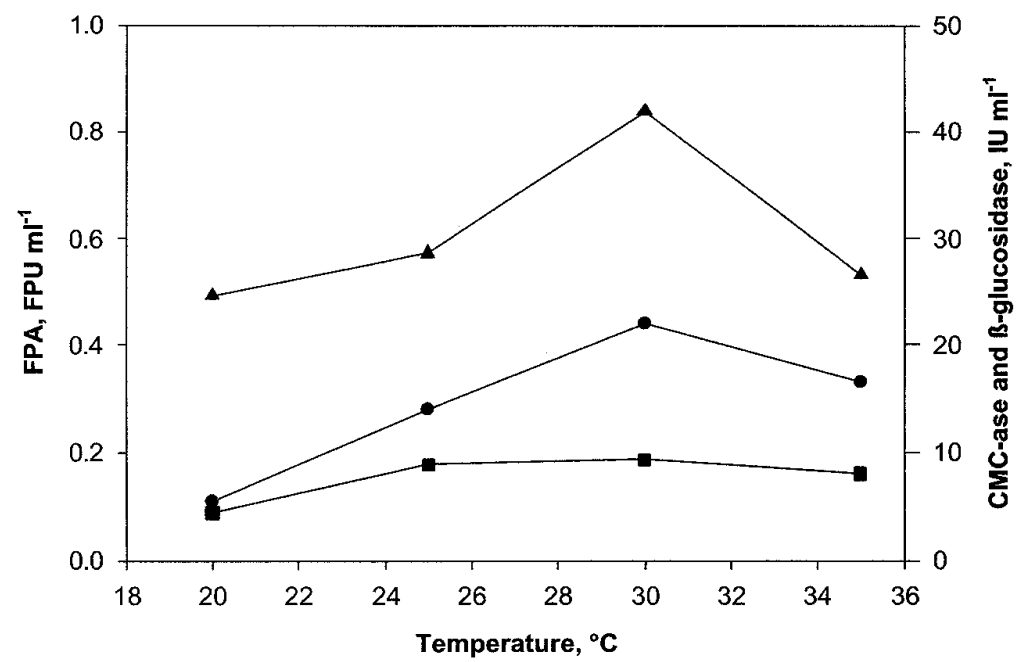

Fig. 5. The effect of incubation temperature on the cellulase production of A. niger using sugar cane bagasse. Filter paper activity (FPA): $\bullet$; $\beta$-glucosidase activity: $\mathbf{\Lambda}$; CMC-ase activity: 
Similar results were obtained by KNAPP and LEGG (1986), DOPPELBAUER and co-workers (1987), BASTANDE (1992), KHALAF ALLAH and co-workers (1993).

The effect of agitation speed on the cellulase production was investigated by varying the speed between 100 and 300 r.p.m. Figure 6 shows the results obtained. It can ben seen that the enzyme production was increased 4.4 times at 300 r.p.m. compared to the control cultivation. These results were in agreement with that reported by MAGNELLI and co-workers (1996) TÜRKER and MAVITUNA (1987) Buswell and CHANG (1994) and SILVA and co-workers (1995). RECZEY and co-workers (1996) used 350 r.p.m. as a good agitation value for cellulases production by T. reesei RUT C30.

\subsection{Hydrolytic capacity of cellulases produced by A. niger}

The results of hydrolysis experiments obtained with cellulases produced by A. niger are summarized in Table 1. It can be seen that untreated materials exerted great resistance towards enzymatic attack, which is due to the strong physical interaction between the components of the naive lignocellulosic materials. Hemicellulose acts as a glue between the lignin and cellulose molecules. By removing the hemicellulose fraction, enzymatic accessibility can be considerably increased.

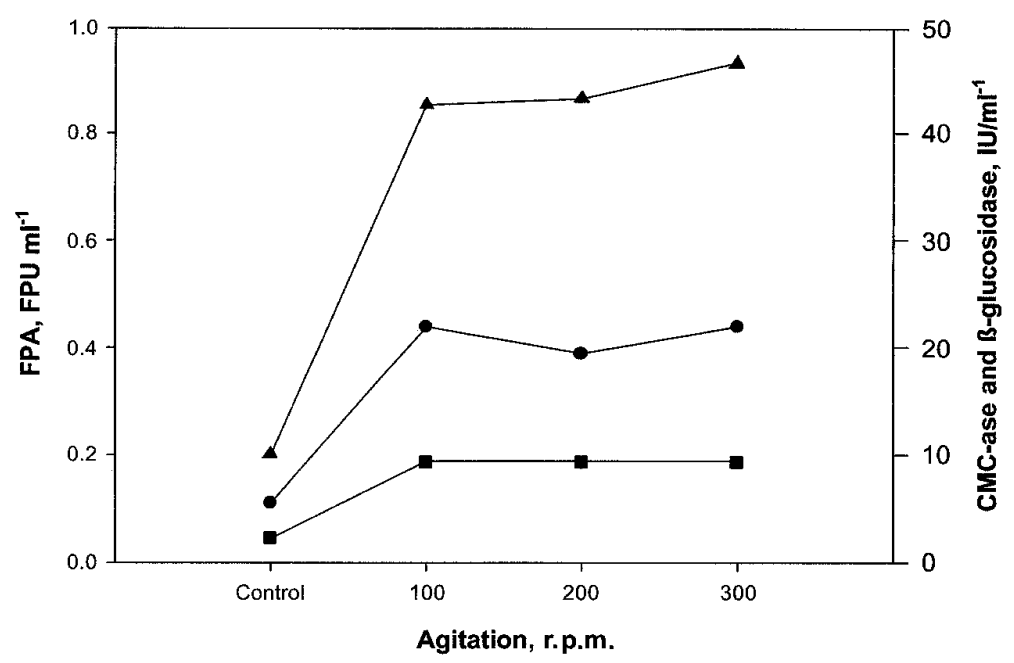

Fig. 6. The effect of agitation on the cellulase production of A. niger using sugar cane bagasse. Filter paper activity (FPA): $\bullet ; \beta$-glucosidase activity: $\mathbf{\Lambda}$; CMC-ase activity: 
Table 1

Effect of A. niger cellulases on the saccharification process

\begin{tabular}{|c|c|c|c|}
\hline \multirow{2}{*}{ Cellulosic subs } & & \multicolumn{2}{|c|}{$\begin{array}{l}\text { A. niger cellulases } \\
\text { produced on untreated } \\
\text { sugar cane bagasse }\end{array}$} \\
\hline & & $\begin{array}{c}\text { Glucose } \\
\left(\mathrm{mg} \mathrm{ml}^{-1}\right)\end{array}$ & $\%$ Saccharification \\
\hline \multirow[t]{3}{*}{ Rice straw } & Untreated & 0.99 & 4.45 \\
\hline & Acid-steam treated & 6.91 & 31.09 \\
\hline & Alkaline treated & 12.13 & 54.58 \\
\hline \multirow[t]{3}{*}{ Cotton stalks } & Untreated & 1.38 & 6.21 \\
\hline & Acid-steam treated & 7.57 & 34.06 \\
\hline & Alkaline treated & 11.12 & 50.04 \\
\hline \multirow[t]{3}{*}{ Sugar cane bagasse } & Untreated & 1.52 & 6.84 \\
\hline & Acid-steam treated & 4.10 & 18.45 \\
\hline & Alkaline treated & 8.17 & 36.76 \\
\hline
\end{tabular}

Conditions: $2 \%$ substrate, $0.2 \mathrm{mg}$ enzyme/g substrate, $0.3 \mathrm{~g} \mathrm{l}^{-1}$ sodium azide, $48 \mathrm{~h}, 50{ }^{\circ} \mathrm{C}, 100$ r.p.m., acetate buffer $\mathrm{pH} 4.8$

Furthermore, it is a generally accepted fact that during pretreatment reduction in cellulose crystallinity occurs, which results in higher hydrolysis rates and yields (CARRASCO et al., 1994). Acid-steam treatment appears to be an effective method to increase enzymatic digestibility. A saccharification degree of $34 \%$ was observed in case of cotton stalks. Treatment with alkaline proved to be the best method and a conversion of $55 \%$ was obtained with rice straw, while the same value for cotton stalks was $50 \%$. The successfulness of alkaline treatment is probably due to its complex action on the lignocellulosic biomass. Besides the increase of the available surface for enzymatic hydrolysis and reducing cellulose crystallinity, the partial hydrolysis of hemicellulose and swelling of the cellulose occur.

\subsection{Lactic acid production using rice straw}

In a set of experiments rice straw was used as substrate for lactic acid production. Two different options were compared, i.e. separate hydrolysis and fermentation (SHF) and simultaneous saccharification and fermentation (SSF).

In the SHF experiments $L$. delbrueckii was cultivated on the hydrolysate of alkali treated rice straw at $\mathrm{pH} 4.8$ and $45{ }^{\circ} \mathrm{C}$. The results are shown in Fig. 7. The concentration of lactic acid in the fermentation broth was about $40 \mathrm{~g} \mathrm{l}^{-1}$ after 4 days of 
incubation, which was considerably higher (about 50\%) than reported by PARAJO and co-workers (1996) using eucalyptus wood hydrolysate. After 4 days of residence time, about $84 \%$ of the initial glucose was converted to lactic acid. Addition of $\mathrm{CaCO}_{3}$ to the medium prevented acidification due to lactic acid formation, and an average $\mathrm{pH}$ of around 4.65 was observed. Significantly higher yields were obtained by MCCASKEY and co-workers (1994) using municipal waste hydrolysates. About $65 \mathrm{gl}^{-1}$ lactic acid concentration was obtained from $100 \mathrm{~g}^{-1}$ glucose containing medium.

The results obtained with SSF experiments using $6 \mathrm{wt} \%$ alkaline treated rice straw are summarized in Fig. 8. The concentration of produced lactic acid continuously increased reaching a maximum concentration of $34 \mathrm{gl}^{-1}$, which means a $57 \%$ conversion of rice straw after 5 days of incubation time. Due to the $\mathrm{CaCO}_{3}$ addition the $\mathrm{pH}$ of the fermentation did not fluctuate much and was between 4.6 and 4.8. ABE and TAKAGI (1991) using milled newspaper reached a lactic acid concentration of $53 \mathrm{~g} \mathrm{l}^{-1}$ after 5-day incubation. The conversion of rice straw to lactic acid was about $57 \%$ when SSF was used, while only $50 \%$ conversion was obtained with the SHF technique. From the results it can be concluded that SSF technique for lactic acid production was advantageous compared to SHF. Therefore, the factors affecting the lactic acid production using SSF were investigated.

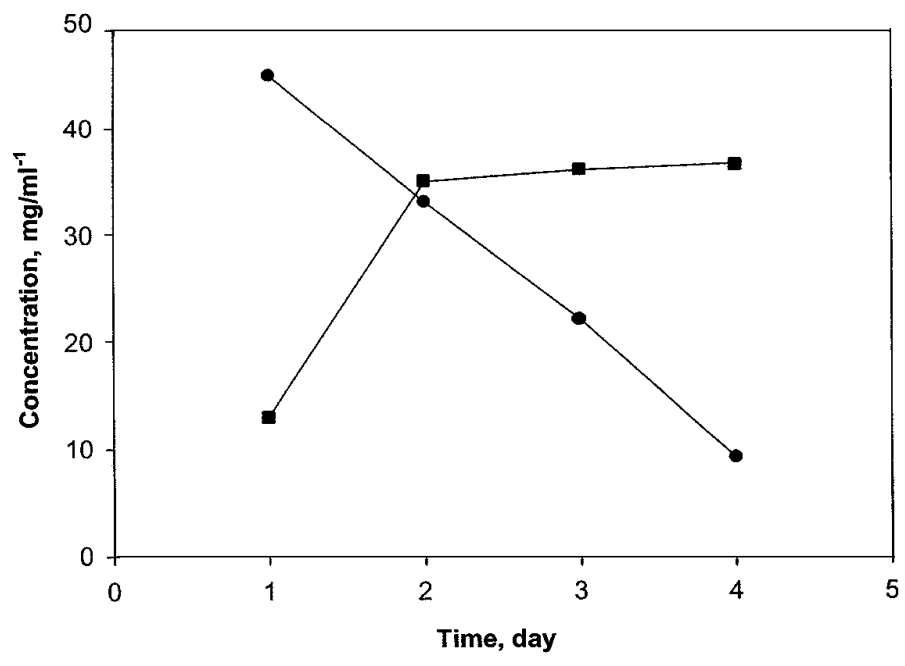

Fig. 7. Lactic acid production using SHF. Glucose: $\bullet$; Lactic acid: 


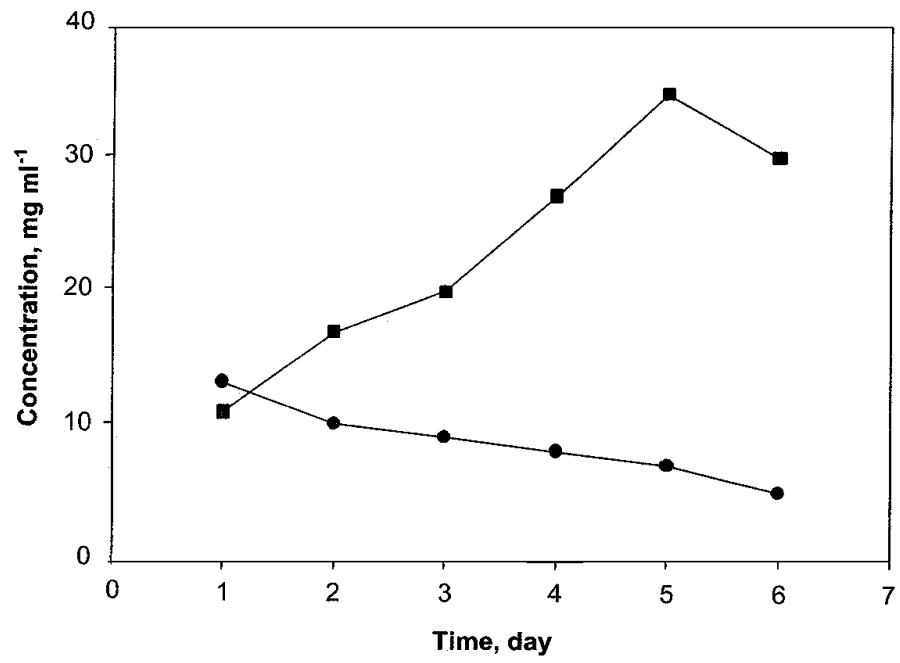

Fig. 8. Lactic acid production using SSF. Glucose: $\bullet$; Lactic acid:

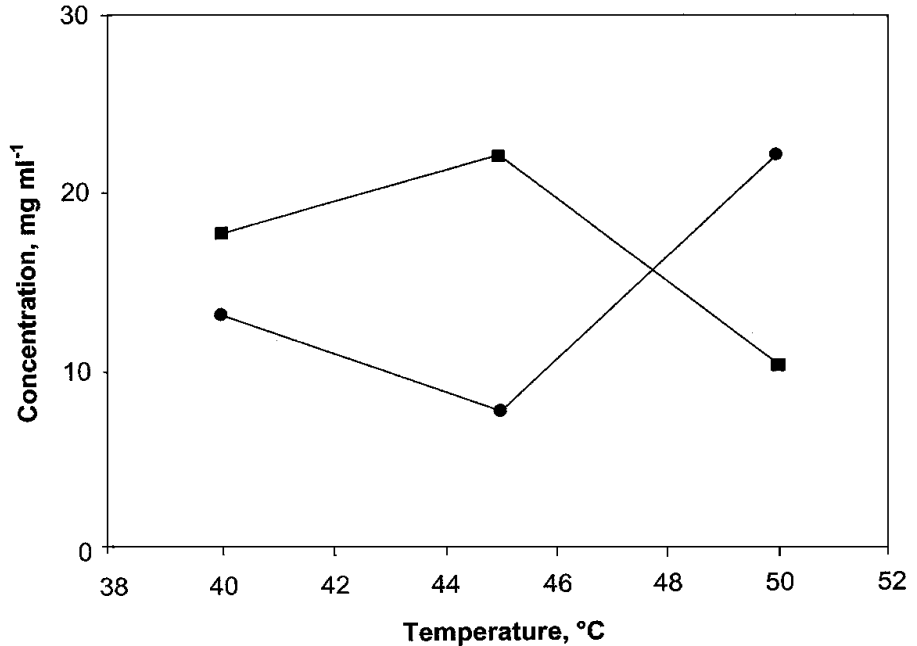

Fig. 9. The effect of incubation temperature on lactic acid production using the SSF technique. Concentrations of glucose $(\bullet)$; and lactic acid $(\square)$ obtained after $48 \mathrm{~h}$ of residence time 
2.3.1. The effect of $\mathrm{pH}$ on the lactic acid production. The effect of medium $\mathrm{pH}$ as one of the most important factors on the SSF technique was investigated. Calcium carbonate was used to prevent the acidification caused by the lactic acid produced during fermentation. The culture medium was supplemented with $0.6 \mathrm{~g} \mathrm{CaCO}_{3} / \mathrm{g}$ substrate. The obtained results showed that $\mathrm{pH} 4.8$ was the optimal $\mathrm{pH}$ for lactic acid production (data not shown).

2.3.2. The effect of incubation temperature on lactic acid production. To investigate the effect of incubation temperature on lactic acid production in the SSF experiments, three different temperatures i.e. 40,45 and $50^{\circ} \mathrm{C}$ were examined. Experiments were run for $48 \mathrm{~h}$. As it is shown in Fig. 9 the optimal temperature for lactic acid production was at $45^{\circ} \mathrm{C}$.

At $40{ }^{\circ} \mathrm{C} 13 \%$ lower, while at $50{ }^{\circ} \mathrm{C}$ almost $50 \%$ lower lactic acid concentrations were obtained compared to that of reached at $45^{\circ} \mathrm{C}$. These results were not surprising at all because $45^{\circ} \mathrm{C}$ was the optimal temperature for the growth of $L$. delbrueckii. These results showed good agreements with the results reported in the literature (PARAJO et al., 1997).

\section{Conclusions}

For efficient conversion of lignocellulosic materials to lactic acid with SSF technique enzyme preparation with high cellulase activity is required. The cellulase production of A. niger using sugar cane bagasse was optimized. The optimal amount and quality of nitrogen source was determined, and tryptone was found to be the best nitrogen source. It was shown that the addition of surfactants to the culture medium increased the extracellular amount of cellulases. The effect of incubation temperature as well as the $\mathrm{pH}$ and the agitation speed on the cellulase production of A. niger was examined and optimized.

It is known that the amount of cellulases produced by Aspergillus strains is not sufficient for efficient conversion of lignocellulosic biomass using the SSF technique. Therefore, in the SHF and SSF conversion of alkali treated rice straw T. koningii cellulases were used. It was shown that SSF resulted in good conversion of rice straw to lactic acid. 


\section{References}

ABE, S. \& TAKAGI, M. (1991): Simultaneous saccharification and fermentation of cellulose to lactic acid. Biotechnol. Bioengng., 37, 93-96.

BARKER, S. B. \& SUMMERSON, W. H. (1941): The colorimetric determination of lactic acid in biological material. J. biol. Chem., 138, 535-554.

BASTAWDE, K. B. (1992): Cellulolytic enzymes of a thermotolerant Aspergillus terreus strain and their action on cellulosic substrates. World J. microbial Biotechnol., 8, 45-49.

Buswell, J. A. \& ChANG, S. (1994): Biomass and extracellular hydrolytic enzyme production by six mushroom species grown on soybean waste. Biotechnol. Lett., 16, 1317-1322.

Carrasco, J. E., Saiz, M., NAVArro, A., Soriano, P., SAez, F. \& Martinez, J. M. (1994): Effect of dilute acid and steam explosion pretreatments on the cellulose structure and kinetics of cellulosic fraction hydrolysis by dilute acids in lignocellulosic materials. Appl. Biochem. Biotechnol., 45/46, $23-34$.

Demiric, A., Pometto, A. L. \& Johnson, K. E. (1993): Evaluation of biofilm reactor solid support for mixed culture lactic acid production. Appl. Microbiol. Biotechnol., 38, 728-733.

Doppelbauer, R., Esterbauer, H., Steiner, W., Lafferty R. M. \& Steinmuller, H. (1987): The use of lignocellulosic wastes for production of cellulase by Trichoderma reesei. Appl. Microbiol. Biotechnol., 26, 485-494.

El-Hawary, F. I. \& Mostafa, Y. S. (2001): Factors affecting cellulase production by Trichoderma koningii. Acta Alimentaria, 30, 3-13.

HAHN-HAGERDAL, B. (1996): Ethanolic fermentation of lignocellulose hydrolysates. Appl. Biochem. Biotechnol., 57/58, 195-199.

HOFVENDAHL, K. \& HAHN-HAGERDAL, B. (1997): L-lactic acid production from whole wheat flour hydrolysate using strains of Lactobacilli and Lactococci. Enzyme microbial. Technol., 20, 301-307.

Hung, B. R., Lara, L., Parton, M. A., Ugarava, N. N., Bechstedt, W. \& Clappes, S. (1988): Tween 80 and proteose peptone effect on cellulase production. Acta Biotechnol., 8, 461-464.

KADEMIC, A. \& BARATTI, J. (1996): Batch fermentation kinetics of ethanol production by Zymomonas mobilis on cellulose hydrolysate. Biotechnol. Lett., 18, 643-648.

KatZen, R. \& MonceauX, D. A. (1995): Development of bioconversion of cellulosic wastes. Appl. Biochem. Biotechnol., 51/52, 585-592.

Khalaf Allah, A. M., ElwaKeIl, F. A. \& El-FanRa, S. A. (1993): Production of cellulase by Aspergillus and Trichoderma sp. on soybean hulls. Res. Bull. Home Econ. Menofiya Univ., 3 (1), 33-34.

Kinnersley, A. M., ScotT, T. C., YopP, J. H. \& Whitten, G. H. (1990): Promotion of plant growth by polymers of lactic acid. Plant Growth Regul., 9, 137-146.

KnAPP, J. S. \& LEGG, M. (1986): The effect of different cellulosic growth substrates and $\mathrm{pH}$ on the production of cellulolytic enzymes by Trichoderma reesei. J. appl. Bacteriology, 61, 319-329.

LAdish, M. R. \& SvarczKopf, J. A. (1991): Ethanol production and the cost of fermentable sugars from biomass. Bioresource Technol., 36, 83-95.

Lezinou, V., Christakopoulos, P., KeKos, D. \& MACRIS, B. J. (1994): Simultaneous saccharification and fermentation of sweet sorghum carbohydrates to ethanol in a fed-batch process. Biotechnol. Lett., 16, 983-988.

LONG, K. \& KNAPP, J. S. (1991): The effect of Junlon PW110 and Tween 80 on the production of cellulolytic enzymes by Coprinus cinereus. Mycol. Res., 95, 1077-1081.

Magnelli, P., Ramos, A. M. \& Forchiassin, F. (1996): Factors influencing cellulase production by Saccobolus saccoboloides. Mycologia, 88, 249-255. 
Mandels, M., ANdReotti, R. \& Roche, C. (1976): Measurement of saccharifying cellulase. Biotechnol. Bioengng. Symp., 6, 21-33.

McCaskey, T. A., Zzou, S. D., BritT, S. N. \& StRickland, R. (1994): Bioconversion of municipal solid waste to lactic acid by Lactobacillus species. Appl. Biochem. Biotechnol., 45/46, 555-566.

Mercier, P., Yenushalmi, L., Rouleau, D. \& Dochain, D. (1992): Kinetics of lactic acid fermentation on glucose and corn by Lactobacillus amylophilus. J. Chem. Technol. Biotechnol., 55, 111-121.

MiLLER, G. L. (1959): Use of dinitrosalicylic acid for determination of reducing sugar. Anal. Chem., 31, 426-428.

Mulligan, C. N., SaFI, B. F. \& Groleau, D. (1991): Continuous production of ammonium lactate by Streptococcus cremoris in a three stage reactor. Biotechnol. Bioengng., 38, 1173-1181.

Norton, S., Lacroix, C. \& Vuillemard, J. C. (1994): Kinetic study of continuous whey permeate fermentation by immobilized Lactobacillus helveticus for lactic acid production. Enzyme microbial Technol., 16, 457-466.

OlsSON, L. \& HAHN-HAGERDAL, B. (1996): Fermentation of lignocellulosic hydrolysates for ethanol production. Enzyme microbial Technol., 18, 312-331.

Parajo, J. C., Alonso, J. L. \& SAntos, V. (1996): Lactic acid from wood. Proc. Biochem., 31, 271-280.

PARAJo, J. C., Alonso, J. L. \& Moldes, A. B. (1997): Production of lactic acid from lignocellulose in a single stage of hydrolysis and fermentation. Fd Biotechnol., 11, 45-58.

PhILIPPIDIS, G. P. \& SMITH, T. K. (1995): Limiting factors in the simultaneous saccharification and fermentation process for conversion of cellulosic biomass to fuel ethanol. Appl. Biochem. Biotechnol., 51/52, 117-124.

Reczey, K., Stalbrand, H., Persson, I., Hahn-Hagerdal, B. \& TJerneld, F. (1990): Continuous cellobiose hydrolysis using self-immobilized $\beta$-glucosidase from Aspergillus phoenicis QM 329 in a fluidized bed reactor. Appl. Biochem. Biotechnol., 24/25, 637-649.

ReCZey, K., Szengyel, Zs., EkLund, R. \& ZACChI, G. (1996): Cellulase production by T. reesei. Bioresource Technol., 57, 25-30.

Silva, S., Elmore, B. B. \& HuCKABAy, H. K. (1995): Cellulase activity of Trichoderma reesei RUT-C30 on municipal solid waste. Appl. Biochem. Biotechnol., 51/52, 145-153.

StUTZENBERGER, F. J. (1987): Component specific stimulation of cellulase secretion in Thermomonospora curvata by the surfactant Tween 80. J. appl. Bacteriology, 63, 239-244.

TÜRKER, M. \& MAVITUNA, F. (1987): Production of cellulase by freely suspended and immobilized cells of Trichoderma reesei. Enzyme microbial Technol., 9, 739-743. 